\title{
PENGEMBANGAN BUKU AJAR ILMU PENGETAHUAN ALAM BERBASIS SAINS TEKNOLOGI MASYARAKAT
}

\author{
Sri Yamtinah, Roemintoyo, dan Alifah Kartikasari \\ Fakultas Keguruan dan Ilmu Pendidikan Universitas Sebelas Maret Surakarta Indonesia \\ email: jengtina@staff.uns.ac.id
}

\begin{abstract}
Abstrak
Penelitian ini bertujuan untuk mengembangkan buku ajar IPA berbasis Sains Teknologi Masyarakat (STM) di sekolah dasar. Metode yang digunakan adalah metode penelitian dan pengembangan. Prosedur pengembangan meliputi dua tahap, yakni studi pendahuluan dan pengembangan prototipe. Subjek penelitian adalah lima orang guru dan 27 peserta didik kelas IV sekolah dasar untuk tahap ujicoba terbatas. Sampel untuk uji coba luas sebanyak 49 peserta didik dengan desain praeksperimental dan untuk uji efektivitas dengan desain quasi eksperimen sebanyak 43 peserta didik. Data kualitatif yang diperoleh dari hasil wawancara, observasi, dan kajian pustaka dianalisis dengan teknik interaktif model Miles dan Huberman untuk memperoleh deskripsi naratif. Data kuantitatif diperoleh dari tes belajar kognitif yang telah memenuhi kriteria validitas dan reliabilitas. Analisis data kuantitatif dilakukan dengan teknik paired dan independent t-test. Hasil penelitian ini menunjukkan bahwa prototipe buku ajar IPA berbasis STM untuk tema sumber daya alam yang dikembangkan sudah layak menurut tinjauan ahli dan direspons baik oleh guru dan peserta didik. Penggunaan bahan ajar IPA berbasis STM secara signifikan mempengaruhi prestasi belajar peserta didik.
\end{abstract}

Kata kunci: buku ajar IPA, Sains Teknologi Masyarakat, sekolah dasar

\section{DEVELOPING SCIENCE TEXTBOOK BASED ON SCIENCE TECHNOLOGY SOCIETY}

\begin{abstract}
This study was aimed at developing a science textbook based on Science Technology Society (STM) for primary school. The method used was research and development (R\&D). The development procedure included two stages, namely a preliminary study and prototype development. The research subjects were 5 teachers and 27 students in grade IV elementary school for the limited trial phase. The samples for the broad trial were 49 students with a pre-experimental design and for effectiveness tests with a quasi-experimental design were 43 students. Qualitative data obtained from interviews, observations and literature reviews were analyzed using the interactive techniques proposed in the Miles \& Huberman model to obtain narrative descriptions. The quantitative data obtained from cognitive learning tests have met the criteria of validity and reliability. The quantitative data analysis was performed using paired techniques and independent t-tests. The results show that the developed prototype of the STM-based science textbook for the theme of natural resources is appropriate according to expert reviews and responded to both by teachers and students. The use of STM-based science teaching materials significantly influences students' learning achievement.
\end{abstract}

Keywords: science textbook, science technology society, primary school 


\section{PENDAHULUAN}

Tantangan pendidikan abad 21 saat ini adalah untuk menyiapkan sumber daya manusia agar memiliki kemampuan berkomunikasi dan penguasaan ilmu pengetahuan dan teknologi melalui proses pembelajaran. Direktorat Pem-binaan Sekolah Menengah Atas $(2017$, p. 6) dalam Panduan Implementasi Kecakapan Abad 21 juga menegaskan bahwa kompetensi kecakapan abad 21 meliputi kecakapan berpikir kritis dan pemecahan masalah, kecakapan berkomunikasi, kreativitas dan inovasi, dan kolaborasi. Keempat kecakapan atau kemampuan peserta didik tersebut dibina dan dikembangkan di dalam setiap mata pelajaran. Untuk menjawab tantangan global manusia Indonesia perlu memiliki kemampuan berfikir tingkat tinggi, yang dapat diwujudkan dengan pendidikan IPA. Pendidikan IPA diwujudkan melalui pembelajaran IPA. Pembelajaran IPA memiliki potensi yang sangat besar dalam upaya membangun bangsa, mengingat berbagai perkembangan teknologi ber-poros pada penelitian IPA.

IPA merupakan salah satu mata pelajaran pokok dalam kurikulum pendidikan di Indonesia, termasuk pada jenjang sekolah dasar. Ada dua hal yang tidak dapat dipisahkan dalam IPA yaitu IPA sebagai produk (pengetahuan IPA sebagai pengetahuan faktual, konseptual, prosedural, dan metakognitif) dan IPA sebagai proses dalam bentuk kerja ilmiah (Wisudawati \& Sulistyowati, 2014). IPA di sekolah dasar umumnya bertujuan untuk menanamkan konsep-konsep dasar pembelajaran IPA yang dapat berguna bagi peserta didik untuk dapat menyelesaikan masalah-masalah yang ada di masyarakat. Saat ini pelajaran IPA dianggap sulit dan menjadi pelajaran hafalan yang monoton oleh sebagian besar peserta didik (Rosyidah, Sudarmin, \& Kusoro, 2013).
Hasil penelitian pendahuluan yang dilakukan di beberapa sekolah menghasilkan kesimpulan bahwa buku ajar yang digunakan telah terintegrasi dengan beberapa mata pelajaran, namun isi materi pelajaran yang kurang mendalam. Sebagian besar buku ajar hanya berisi lembar kerja dan lembar diskusi peserta didik. Hal yang demikian menyebabkan kurangnya penanaman konsep dasar IPA dalam diri peserta didik, terutama peserta didik sekolah dasar.

Buku ajar yang baik hendaknya disusun secara sistematis dan mudah dipahami peserta didik. Buku ajar yang baik harus memiliki komposisi yang pas dari sisi visual dan isinya. Tampilan visual yang terlalu banyak pada buku ajar IPA, justru dapat membuat peserta didik kesulitan dalam memahami konsep IPA (Cook, 2008). Buku ajar semestinya dapat memfasilitasi kebutuhan untuk mengembangkan pengetahuan konseptual dan mengatasi kesalahpahaman peserta didik, sehingga pengembangan buku ajar saat ini sangat dibutuhkan (Sinatra \& Broughton, 2011).

Kurikulum 2013 sudah menggunakan pendekatan saintifik sehingga seharusnya ada substansi yang mengajak peserta didik untuk lebih aktif pada buku ajar yang digunakan. Faktanya kegiatan percobaan masih belum terlihat pada buku ajar. Kegiatan peserta didik hanya sebatas mengamati gambar dan mengisi tugas individu pada kolom yang telah tersedia. Terkait dengan dengan teknologi dan masyarakat, sudah tercantum materi yang berhubungan dengan keduanya, akantetapi materi tersebut masih sedikit dan terbatas pada mengamati gambar. Selain itu, belum ada kegiatan ilmiah yang sesuai yang dapat mengajak peserta didik untuk melakukan kegiatan berpikir ilmiah dan menggunakan masyarakat sebagai 
sumber belajar. Di sisi lain, kondisi lingkungan dan masyarakat sekitar dapat dijadikan sebagai sumber belajar bagi peserta didik. Hal tersebut sesuai dengan pendapat Nurohman (2016) yang menyebutkan bahwa proses pendidikan sesungguhnya dijalankan dalam rangka memenuhi kebutuhan akan sumber daya manusia yang mampu menyelesaikan persoalan lokal yang melingkupinya.

Penggunaan buku ajar yang mengaitkan pembelajaran IPA dengan teknologi serta kegunaan dan kebutuhan masyarakat, konsep-konsep yang telah dipelajari dan dikuasai peserta didik diharapkan dapat bermanfaat bagi dirinya dan dapat digunakan untuk menyelesaikan masalah yang dihadapinya maupun masalah lingkungan sosialnya. Hasil penelitian terdahulu menunjukkan bahwa buku ajar IPA berbasis Sains Teknologi Masyarakat dapat meningkatkan pemahaman didik terhadap konsep IPA, karena disusun berdasarkan kehidupan sehari-hari (Binadja, 2006, p. 36).

Penggunaan model pembelajaran model sains teknologi masyarakat yang memanfaatkan fenomena atau kejadian dalam kehidupan sehari-hari dapat meningkatkan kemampuan peserta didik dalam memecahkan masalah (Rahmawati, Rahman, \& Amprasto, 2017). Pembelajaran berbasis Sains Teknologi Masyarakat dapat dirancang dan dikembangkan sebagai sesuatu yang kompleks untuk dapat mengembangkan keterampilan berpikir kritis, ilmiah dan menjadi warga negara yang melek teknologi (Pedretti, 2003, p. 219).

Berdasarkan pemaparan di atas, penelitian ini bertujuan mengembangkan buku ajar IPA berbasis sains, teknologi, dan masyarakat di sekolah dasar sehingga pemahaman peserta didik mengenai IPAdan fungsinya dalam masyarakat dapat lebih ditingkatkan. Pengembangan buku ajar IPA berbasis Sains Teknologi Masyarakat disusun berdasarkan permasalah yang terdapat di lingkungan peserta didik. Masalah yang diambil merupakan masalah yang sangat sederhana, seperti cara menjaga lingkungan di sekitar sekolah. Dengan demikian peserta didik dapat menerapkan apa yang sudah mereka pelajari untuk menyelesaikan masalah di kehidupan nyata dengan cara yang sederhana. Dengan dilakukan pengembangan ini, diharapkan dapat menjawab permasalahan buku ajar di sekolah dasar yang memiliki sedikit konten materi didalamnya dan tidak kontekstual dalam menghubungkan sains, teknologi, dan msyarakat.

\section{METODE}

Penelitian ini merupakan penelitian pengembangan buku ajar berbasis Sains Teknologi Masyarakat dengan prosedur pengembangan Research and Development (R\&D) dari Borg and Gall (2003). Produk buku ajar IPA berbasis Sains Teknologi Masyarakat disusun dengan sintaks pembelajaran Sains Teknologi Masyarakat yang terdiri atas: pembentukan konsep, aplikasi konsep dalam kehidupan seharihari, dan pemantapan konsep.

Desain pengembangan dalam penelitian ini menggunakan 10 tahapan yakni: tahap pendahuluan dan pengumpulan informasi, tahap perencanaan, tahap pengembangan bentuk awal produk, uji coba terbatas, revisi produk I, uji lapangan utama (uji skala luas), revisi produk II, uji pelaksanaan lapangan (uji efektivitas), revisi final, dan diseminasi dan implementasi.

Tahap pertama, studi pendahuluan dan pengumpulan informasi dilakukan dengan melakukan analisis konsep-konsep yang berkaitan dengan produk berupa buku ajar IPA berbasis Sains Teknologi 
Masyarakat. Langkah selanjutnya melakukan survei lapangan untuk mengidentifikasi permasalahan yang terjadi pada pembelajaran IPA di 5 sekolah dasar di Kecamatan Gatak Kabupaten Sukoharjo menggunakan metode observasi dan wawancara semi terstruktur.

Tahap kedua adalah perencanaan yaitu menyiapkan format draft buku ajar, kompetensi dasar dan indikator-indikator kompetensi pada tema Sumber Daya Alam. Tahap ketiga yaitu pengembangan prototipe produk berupa draft buku ajar IPA berbasis Sains Teknologi Masyarakat. Prototipe ini divalidasi oleh 8 orang ahli yang terdiri dari ahli materi, ahli bahasa, ahli media dan ahli pembelajaran SD.

Tahap keempat merupakan ujicoba terbatas menggunakan teknik pengumpulan data berupa wawancara kepada guru dan siswa untuk menilai prototipe tersebut dari aspek keterbacaan. Subjek yang terlibat pada uji coba terbatas ini adalah 27 siswa dan guru dari SDN Trosemi 02. Beberapa masukan dari uji coba terbatas ini ditindaklanjuti dengan revisi produk I sebagai langkah kelima.

Tahap selanjutnya yaitu keenam uji coba luas yang berfungsi untuk membuktikan bahwa prototype memenuhi syarat atau layak untuk digunakan. Pengujian skala luas ini menggunakan teknik analisis kuantitatif paired sample t-test. Instrumen yang digunakan untuk analisis kuantitatif ini adalah instrument tes aspek kognitif yang telah divalidasi oleh 8 orang ahli menggunakan validitas isi Aiken. Selain itu, uji coba skala luas ini juga sekaligus digunakan untuk membuktikan reliabilitas dan analisis butir instrumen tes yang digunakan pada ujicoba efektivitas. Selain menggunakan data kuantitatif, tahap ini juga dilakukan wawancara kepada para guru untuk mendapatkan masukan. Subjek yang digunakan pada uji coba luas ini adalah 49 anak dari SDN Krajan 01 dan SDN Trangsan 04. Masukan dari para guru digunakan untuk melakukan revisi II sebagai langkah ketujuh.

Langkah kedelapan adalah uji efektivitas di Kecamatan Gatak Kabupaten Sukoharjo. Sekolah dipilih melalui purposive random sampling yaitu sekolahsekolah yang menerapkan Kurikulum 2013 dalam pembelajarannya. Sekolah yang menjadi sampel pada penelitian ini yaitu SDN Trosemi 02, SDN Krajan 01, SDN Trangsan 04, SDN Belimbing 03, dan SDN Geneng 01.

Uji coba efektivitas ini menggunakan quasi eksperimen dengan desain penelitian pretest-posttest control group design. Pada tahap ini juga dilakukan wawancara dengan guru untuk memperoleh masukan penyempurnaan draft bahan ajar, yang ditindaklanjuti sebagai langkah kesembilan yaitu revisi final. Alur pengembangan buku ajar dapat dilihat pada Gambar 1 .

\section{HASIL PENELITIAN DAN PEMBAHASAN}

Pengembangan bahan ajar IPA berbasis Sains Teknologi Masyarakat merupakan bagian penting dalam pembelajaran IPA Sekolah Dasar. Dilakukan pengamatan lapangan menggunakan tiga teknik pengambilan data yakni; melakukan tes untuk mengetahui kondisi kemampuan pemecahan masalah peserta didik, wawancara, dan observasi dan dokumentasi terhadap pembelajaran IPA. Hasil analisis studi dokumentasi nilai hasil belajar peserta didik pada ulangan akhir semester 2 menunjukkan hasil yang dapat dilihat pada Tabel 1.

Berdasarkan Tabel 1 disimpulkan bahwa nilai ketuntasan peserta didik pada hasil UAS masih tergolong rendah. Dari keempat SD tersebut hanya satu SD yang persentasenya di atas 70\%. Di SDN 
Gambar 1. Alur Pengembangan Buku Ajar IPA Berbasis Sains Teknologi Masyarakat

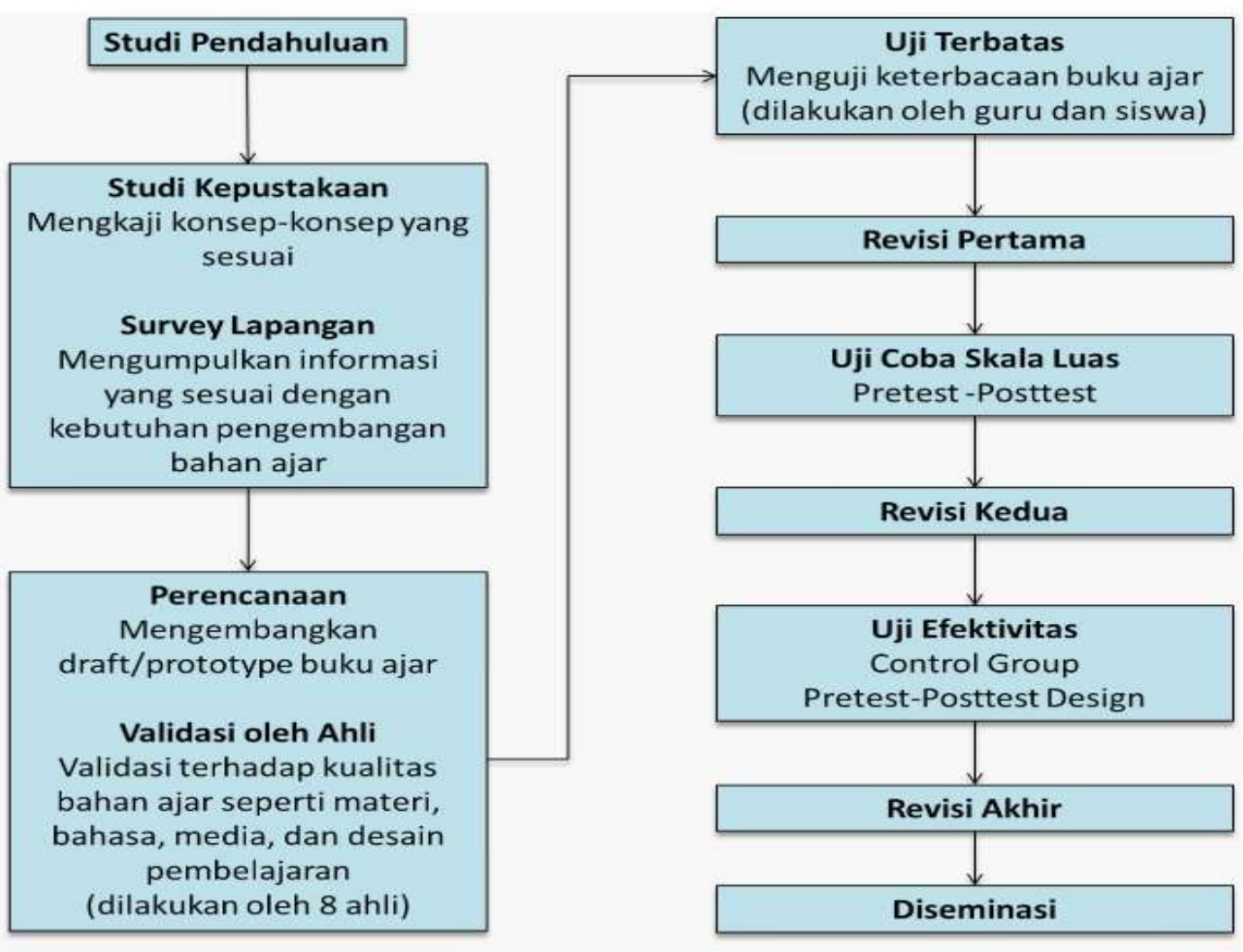

Tabel 1

Persentase Ketuntasan Nilai Ujian Akhir Semester (UAS) Semester Genap

\begin{tabular}{clc}
\hline No & \multicolumn{1}{c}{ Nama Sekolah } & $\begin{array}{c}\text { Persentase Ketuntasan Nilai UAS } \\
\text { Mata Pelajaran IPA }\end{array}$ \\
\hline 1 & SD Geneng 02 & $77 \%$ \\
2 & SD Belimbing 01 & $53 \%$ \\
3 & SD Mayang & $46 \%$ \\
4 & SD Jati 02 & $55 \%$ \\
\hline
\end{tabular}

Geneng 02 peserta didik yang belum tuntas sebanyak 17 peserta didik dari 22 peserta didik, di SDN Belimbing 01 peserta didik yang belum tuntas sebanyak 16 peserta didik dari 30 peserta didik, di SDN Mayang peserta didik yang belum tuntas sebanyak 7 peserta didik dari 15 peserta didik, sedangkan di SDN Jati 02 peserta didik yang belum tuntas sebanyak 10 peserta didik dari 18 peserta didik.

Hasil observasi menunjukkan bahwa bahan ajar IPA yang digunakan di kedua sekolah tersebut adalah buku tematik yang berasal dari pemerintah. Kajian analisis tentang karakteristik bahan ajar IPA difokuskan pada kedua buku tematik 
yang digunakan. Hasil observasi guru saat kegiatan pembelajaran IPA berlangsung menunjukkan hasil yang sama bahwa guru hanya terpaku pada materi yang tercantum pada buku ajar yang digunakan. Dilihat dari metode pembelajaran yang digunakan guru, pembelajaran di kelas masih didominasi dengan kegiatan ceramah dan tanya jawab. Di samping itu, kegiatan yang dilakukan peserta didik selama proses pembelajaran berfokus pada kerja individu, yaitu mengerjakan soal evaluasi yang diberikan guru.

Berdasarkan data observasi, masih tampak bahwa guru kelas IV masih kesulitan dalam menerapkan pembelajaran tematik. Hal ini dikarenakan tahun 2019 merupakan tahun pertama penerapan Kurikulum 2013 di Kecamatan Gatak. Kesulitan guru tampak pada saat kegiatan pembelajaran, guru masih beberapa kali membuka buku pegangan guru untuk mengetahui langkah-langkah yang harus dilakukan selanjutnya. Selain itu, guru masih mencari materi tambahan dari buku KTSPyang digunakan untuk mempermudah dalam menyampaikan materi pembelajaran kepada peserta didik.

Wawancara juga dilakukan pada tahap pengamatan lapangan selain observasi. Wawancara ini bertujuan untuk mengumpulkan informasi mengenai kondisi bahan ajar IPA dan kebutuhan terhadap bahan ajar IPA berbasis Sains Teknologi Masyarakat di lapangan. Kegiatan wawancara dilakukan pada peserta didik dan guru setelah pembelajaran selesai. Berdasarkan hasil wawancara diperoleh data sebagai berikut: materi IPA yang terkandung di dalam buku kurikulum 2013 masih dangkal, nilai IPA masih tergolong rendah dibandingkan dengan mata pelajaran lainnya, sebagian besar peserta didik masih mengalami kesulitan dalam mempelajari konsep- konsep dalam pembelajaran IPA, dan sebagian besar peserta didik masih pasif selama proses pembelajaran berlangsung karena pembelajaran masih berpusat pada guru sehingga peserta didik terlihat kurang aktif dan hanya mendengarkan penjelasan guru.

Pembelajaran IPA hendaknya menggunakan metode pembelajaran yang dapat meningkatkan keaktifan peserta didik. Pada tahap ini diperoleh informasi bahwa guru masih menggunakan metode ceramah. Penggunaan metode ceramah yang terlalu sering menyebabkan peserta didik menjadi pasif selama proses pembelajaran. Hal ini sesuai dengan hasil penelitian Titin, Sunarno, dan Masykuri (2012) yang menyebutkan bahwa pembelajaran dengan metode ceramah menyebabkan peserta didik kurang aktif dalam pembelajaran. Pembelajaran yang demikian menyebabkan peserta didik cenderung hanya berperan sebagai penerima informasi. Peserta didik belum diajak berfikir untuk menyikapi permasalahan yang terjadi dalam kehidupan sehari-hari.

Hasil wawancara juga menghasilkan kesimpulan yang sama dengan hasil observasi. Keterbatasan materi IPA yang terdapat pada buku ajar yang sudah ada menjadi salah satu penyebab rendahnya pemahaman peserta didik terhadap IPA. Hal tersebut menyebabkan kurangnya kuatnya penanaman konsep IPA pada diri peserta didik.

Berdasarkan hasil riset awal atau studi pendahuluan tersebut, maka dapat dilakukan upaya untuk memaksimalkan pembelajaran IPA di sekolah dasar salah satunya dengan mengembangkan bahan ajar. Belawati (2003, pp. 1.4-1.9) menjelaskan bahwa bahan ajar mempunyai beberapa peran bagi guru maupun bagi peserta didik. Peran bahan ajar bagi guru meliputi: menghemat waktu guru dalam mengajar, mengubah 
peran guru dari seorang pengajar menjadi seorang fasilitator, dan meningkatkan proses pembelajaran menjadi lebih efektif dan interaktif. Peran bahan ajar bagi peserta didik meliputi: peserta didik dapat belajar tanpa kehadiran/harus ada guru, peserta didik dapat belajar kapan saja dan dimana saja dikehendaki, peserta didik dapat belajar sesuai dengan kecepatan sendiri, peserta didik dapat belajar menurut urutan yang dipilihnya sendiri, dan membantu potensi untuk menjadi pelajar mandiri.

Pengembangan bahan ajar IPA berbasis Sains Teknologi Masyarakat dinilai sesuai untuk mengatasi permasalah yang terdapat dalam studi pendahuluan. hal tersebut sesuai dengan pendapat Gusmedi, Hasra, dan Kamus (2013) yang menjelaskan bahwa bahan ajar berbasis Sains Teknologi Masyarakat dapat meningkatkan kompetensi peserta didik pada ketiga aspek, yaitu aspek kognitif, afektif, dan psikomotorik. Hal tersebut dikarenakan selama pembelajaran guru dapat memberikan kesempatan kepada peserta didik untuk terlibat secara aktif dalam proses pembelajaran sehingga hasil yang didapatkan tidak hanya konsep atau prinsip-prinsip saja melainkan kegunaannya di masyarakat atau dalam kehidupan sehari-hari.

Analisis dokumen dilakukan untuk mengetahui isi dan cakupan materi yang terdapat pada sumber belajar yang telah digunakan guru dan peserta didik dalam pembelajaran IPA selama ini. Sumber belajar yang dianalisis adalah buku Kurikulum 2013. Adapun hasil analisis dokumen adalah sebagai berikut. Pertama, Kurikulum 2013 telah menggunakan pendekatan saintifik, sehingga sudah ada substansi-substansi yang mengajak peserta didik untuk lebih aktif. Kedua, materi IPA yang terdapat pada buku ajar masih terbatas dan belum mendalam. Dilihat dari buku guru dan buku peserta didik, materi IPA yang terkandung masih sedikit dan terbatas pada unjuk kerja peserta didik, sehingga penanaman konsep dasar IPA masih kurang. Ketiga, kegiatan percobaan masih belum terlihat pada buku. Kegiatan peserta didik hanya sebatas mengamati gambar dan mengisi tugas individu pada kolom yang telah tersedia. Keempat, dalam hubungannya dengan teknologi dan masyarakat, sudah tercantum materi yang behubungan dengan keduanya, akan tetapi materi tersebut masih sedikit dan terbatas pada mengamati gambar. Belum ada kegiatan ilmiah yang mengajak peserta didik untuk berpikir ilmiah dan menggunakan masyarakat sebagai sumber belajar.

Bahan ajar tersebut sebenarnya sudah terdapat substansi-substansi yang mengajak peserta didik untuk lebih aktif, menggunakan pendekatan saintifik sehingga terdapat kegiatan 5M di dalamnya. Materi IPA yang terkandung dalam bahan ajar tersebut masih terbatas dan belum mendalam. Metode yang digunakan guru masih terbatas pada ceramah dan tanya jawab, sehingga hasil belajar peserta didik masih tergolong rendah. Berdasarkan hasil tersebut, perlu adanya pengembangan bahan ajar IPA berbasis Sains Teknologi Masyarakat yang mampu menarik perhatian peserta didik sehingga mampu mendorong peserta didik untuk lebih aktif selama pembelajaran dan mampu mendorong peserta didik bisa berpikir secara ilmiah.

Hasil kajian lapangan dan kajian kepustakaan yang telah dilaksanakan selanjutnya dijadikan dasar untuk mengembangkan buku ajar yang sesuai. Pengembangan yang dimaksud adalah pengembangan buku ajar IPA berbasis Sains Teknologi Masyarakat. Adapun materi yang dikembangkan pada buku ajar adalah materi sumber daya alam. Materi 
tersebut diambil dari Kompetensi Dasar 3.8 yaitu menjelaskan pentingnya upaya keseimbangan dan pelestarian sumber daya alam di lingkungannya.yang terdapat pada Kurikulum 2013. Berdasarkan kompetensi dasar yang telah diambil tersebut, materi yang ada dikembangkan. Pengembangan materi ajar dibagi menjadi lima subbab yang menjadi pokok bahasan pada prototipe produk. Kelima subbab tersebut adalah jenis-jenis sumber daya alam, manfaat sumber daya alam, teknologi pengolahan sumber daya alam, hubungan sumber daya alam dengan lingkungan, dan upaya pelestarian sumber daya alam.

Tahapan selanjutnya adalah tahap pengembangan bentuk awal produk (develop preliminary form of product) yang dilakukan adalah membuat prototipe bahan ajar IPA berbasis Sains Teknologi Masyarakat. Pengembangan prototipe bahan ajar tahap awal dilakukan dengan berpedoman pada perencanaan tujuan, subpokok bahasan, dan tugas peserta didik yang disusun berdasarkan kompetensi dasar yang telah ditentukan. Produk tersebut kemudian disusun dan disesuaikan dengan langkah-langkah yang terdapat pada pembelajaran berbasis Sains Teknologi Masyarakat. Buku ajar tersebut disajikan dalam bentuk cetak. Adapun layout halaman sampul dan penyajian materi yang disajikan pada buku ajar IPA berbasis Sains Teknologi Masyarakat dapat dilihat pada Gambar 2 dan 3.

Buku ajar IPA berbasis Sains Teknologi Masyarakat merupakan bahan ajar yang berbentuk cetak yang bermuatan Sains Teknologi Masyarakat. Dalam bahan ajar ini disajikan materi-materi IPA yang disusun secara sederhana sehingga mudah dipahami peserta didik. Buku ajar ini

Gambar 2. Layout Halaman Sampul

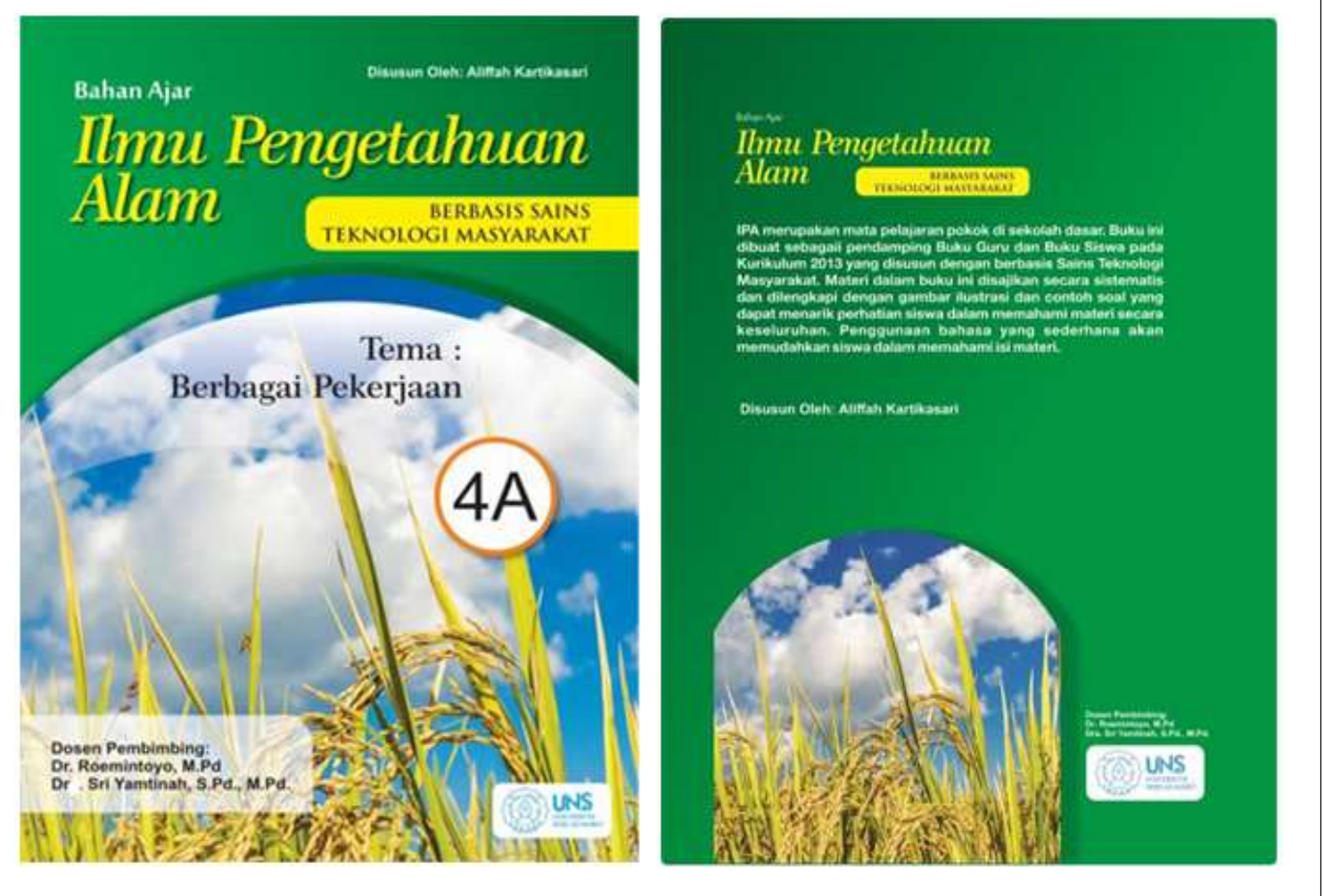


Gambar 3. Materi yang Disajikan pada Buku Ajar

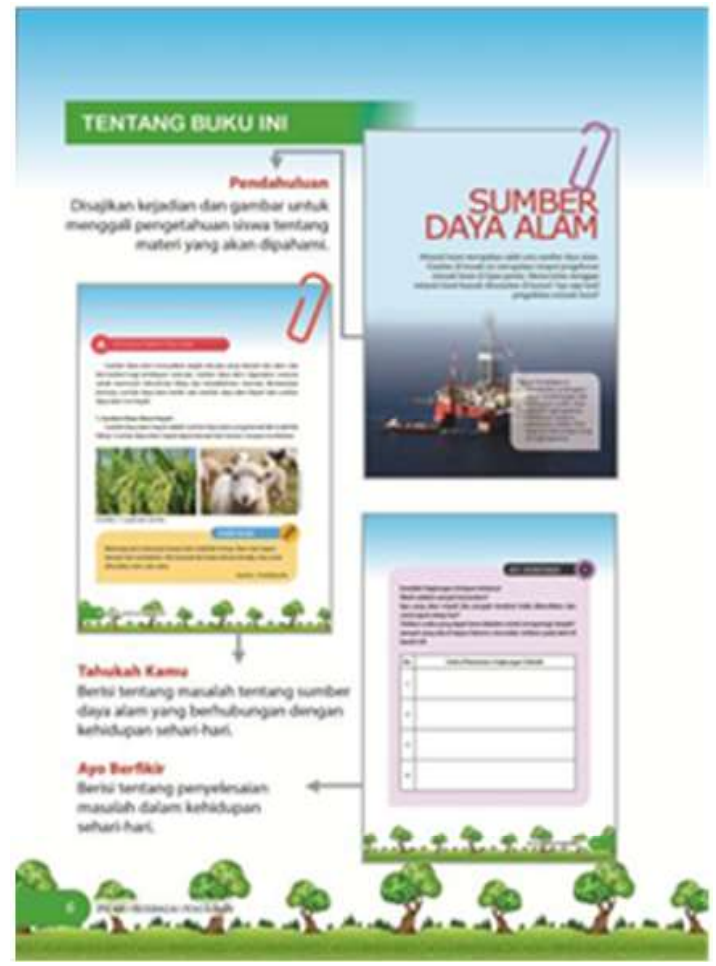

didukung dengan penggunaan gambargambar yang mendukung pengembangan materi, pemilihan bahasa yang interaktif dan komunikatif, soal-soal latihan yang membantu pemahaman peserta didik, dan penggunaan warna-warna yang menarik. Dengan demikian, bahan ajar IPA berbasis Sains Teknologi Masyarakat mampu untuk menumbuhkan minat peserta didik untuk mempelajari materi-materi yang terkandung di dalamnya. Penyajian bahan ajar ini sesuai dengan pendapat Suherman (2008) yang menjelaskan bahwa bahan ajar cetak harus mampu merangsang peserta didik untuk aktif dalam proses belajarnya, bahkan membelajarkan peserta didik untuk dapat menilai kemampuannya sendiri.

Proses validasi dilakukan oleh delapan orang ahli yang berupakan guru dan dosen yang terdiri dari ahli materi IPA, ahli

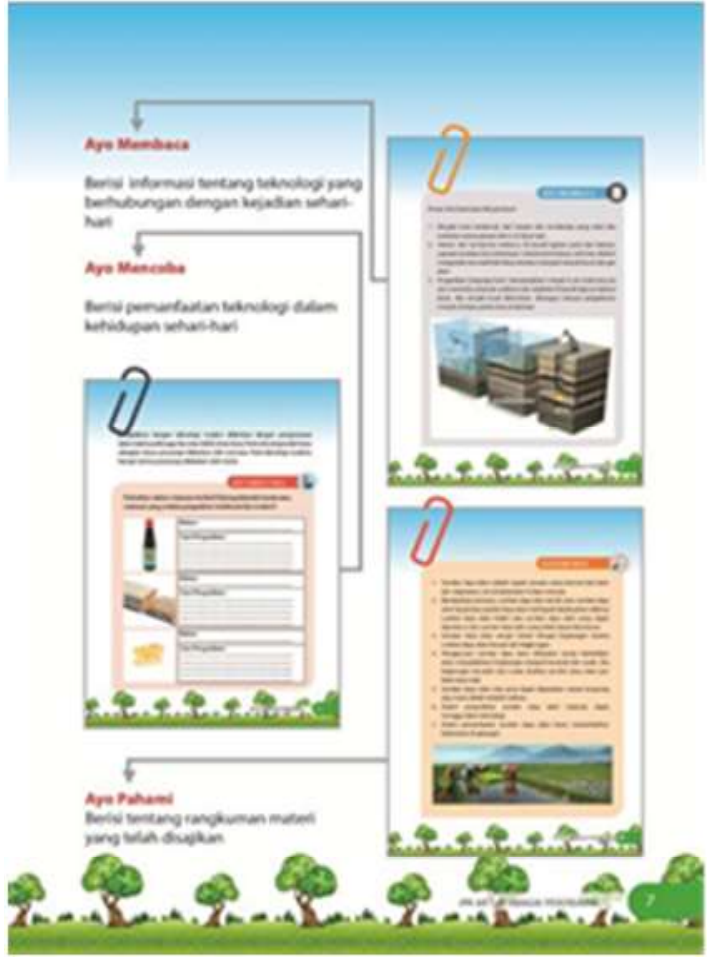

bahasa, ahli media pembelajaran, dan ahli desain. Berdasarkan hasil validasi ahli yang terdiri dari dosen dan praktisi menunjukkan bahwa buku ajar yang dikembangkan masuk ke dalam kategori layak atau baik. Perbaikan telah dilakukan sesuai dengan masukan dari ahli. Materi yang ditambahkan sesuai dengan sintaks pada pembelajaran Sains Teknologi Masyarakat dengan bahasa yang komunikatif.

Dalam penyusunan materi harus memperhatikan kedalaman dan keluasan cakupan materi (Depdiknas, 2008, p. 6). Keluasan materi menggambarkan seberapa banyak materi-materi yang dimasukkan, sedangkan kedalaman materi menyangkut rincian konsep-konsep yang terkandung di dalamnya, yang harus dipelajari oleh peserta didik. Materi pembelajaran perlu diidentifikasi secara tepat agar pencapaian 
kompetensi peserta didik dapat diukur. Selain itu, dengan mengidentifikasi jenisjenis materi yang akan dibelajarkan, guru akan mendapatkan ketepatan dalam pemilihan metode pembelajaran.

Setiap komponen buku ajar disertai contoh-contoh dan gambar yang mudah dipahami peserta didik. Penggunaan gambar yang berwarna-warni dapat menarik perhatian peserta didik. Hal tersebut sesuai dengan yang dikemukakan oleh Prastowo (2012, p. 125), yang menyatakan bahwa gambar-gambar dapat mendukung dan memperjelas isi materi sehingga menimbulkan daya tarik dan mengurangi kebosanan bagi pembaca.

Pengujian buku ajar dilakukan sebanyak tiga kali, yaitu uji coba terbatas yang berfungsi sebagai uji keterbacaan, uji skala menengah yang berfungsi menguji kelayakan produk dan uji efektivitas yang berfungsi melihat efektivitas produk. Hasil uji coba terbatas dan luas melalui observasi dan wawancara menunjukkan hasil pada beberapa aspek seperti yang ditunjukkan pada Tabel 2.

Adapun hasil uji coba luas menunjukkan rata-rata uji gain score sebesar 0,431 yang termasuk kategori perolehan sedang. Hasil pretest dan posttest menunjukkan perbedaan yang cukup baik setelah penggunaan buku ajar IPA berbasis Sains Masyarakat Teknologi dalam pembelajaran IPA seperti yang ditunjukkan pada Tabel 3 .

Melalui uji luas diketahui bahwa dari 30 soal dalam instrumen tes yang

Tabel 2

Hasil Observasi dan Wawancara Uji Coba Terbatas

\begin{tabular}{|c|c|c|}
\hline No & Aspek & Hasil \\
\hline 1 & Isi bahan ajar & $\begin{array}{l}\text { Tidak terdapat kendala yang menyulitkan peserta } \\
\text { didik dalam belajar serta soal yang disediakan pada } \\
\text { lembar kerja dapat mengoptimalkan kegiatan belajar } \\
\text { peserta didik }\end{array}$ \\
\hline 2 & $\begin{array}{l}\text { Penyajian tampilan, } \\
\text { gambar, tabel, dan bagan }\end{array}$ & $\begin{array}{l}\text { Gambar yang digunakan dapat mendukung konten } \\
\text { dengan baik }\end{array}$ \\
\hline 3 & Keterbacaan & $\begin{array}{l}\text { Tata penulisan dan bahasa yang digunakan dalam } \\
\text { buku ajar dapat dipahami dengan baik }\end{array}$ \\
\hline 4 & Pembelajaran & $\begin{array}{l}\text { Bahan ajar yang dikembangkan dalam buku ajar } \\
\text { ini dapat menarik perhatian peserta didik dan dapat } \\
\text { mendorong siswa menjadi lebih aktif dalam belajar }\end{array}$ \\
\hline
\end{tabular}

Tabel 3

\begin{tabular}{clcc}
\multicolumn{4}{c}{ Hasil Rata-rata Uji Gain Score pada Pretest dan Posttest } \\
\hline No & \multicolumn{1}{c}{ Skor } & Pretest & Posttest \\
\hline 1 & Nilai maksimal & 84 & 88 \\
2 & Nilai minimal & 40 & 52 \\
3 & Skor rata-rata & 53,714 & 68,489 \\
4 & Rata-rata uji gain score & \multicolumn{2}{c}{0,431} \\
5 & Keterangan & \multicolumn{2}{c}{ Sedang } \\
\hline
\end{tabular}


digunakan, terdapat 3 soal yang tergolong sukar, 21 soal yang tergolong sedang, dan 6 soal yang tergolong mudah. Adapun daya pembeda dari 30 soal tersebut terdistribusi menjadi 3 kelompok, yaitu kelompok dengan daya pembeda sangat baik sebanyak 25 soal, kelompok dengan daya pembeda baik sebanyak 4 soal, dan kelompok dengan daya pembeda cukup sebanyak 1 soal.

Instrumen ini juga memiliki nilai reliabilitas 0,919 dengan kategori sangat tinggi. Hal ini menunjukkan bahwa instrumen tes yang digunakan sebagai instrumen penilai keefektifan buku ajar telah layak dan sesuai untuk digunakan. Instrumen tes memiliki tingkat kesukaran yang terdistribusi baik (jumlah sedang yang lebih tinggi dari soal sukar dan mudah), daya pembeda yang sangat baik, serta tingkat reliabilitas yang sangat tinggi.

Uji efektivitas dilakukan pada 43 peserta didik dari SDN Belimbing 03 dan SDN Geneng 01 melalui metode kuasi eksperimen. Sebelum melakukan uji efektivitas, peneliti melakukan uji pendahuluan yang terdiri dari uji prasyarat normalitas dan homogenitas, serta uji lanjut independent sample t-test pada kelas kontrol dan kelas eksperimen menggunakan SPSS dengan hasil seperti pada Tabel 4.
Setelah dilakukan uji keseimbangan antara kedua kelas kontrol dan eksperimen, kemudian dilakukan uji efektivitas buku ajar melalui uji hipotesis yang diajukan sebelumnya, yaitu:

$\mathrm{H}_{\mathrm{o}}$ : tidak terdapat perbedaan efektivitas antara bahan ajar IPA berbasis Sains Teknologi Masyarakat dengan bahan ajar IPA yang digunakan guru kelas IV sekolah dasar di Kecamatan Gatak. H1 : bahan ajar IPA berbasis Sains Teknologi Masyarakat lebih efektif dibandingkan dengan bahan ajar IPA yang digunakan guru kelas IV sekolah dasar kecamatan Gatak.

Hasil uji efektivitas beserta uji prasyaratnya disajikan pada Tabel 5. Kelima subbab tersebut adalah jenis-jenis sumber daya alam, manfaat sumber daya alam, teknologi pengolahan sumber daya alam, hubungan sumber daya alam dengan lingkungan, dan upaya pelestarian sumber daya alam.

Penerapan buku ajar yang mengintegrasikan isu sains, teknologi, dan masyarakat berdampak positif pada prestasi belajar kognitif peserta didik SD. Permasalahan yang dekat dengan kehidupan akan mendorong rasa ingin tahu yang lebih besar sehingga menimbulkan motivasi belajar yang tinggi. Sementara itu,

Tabel 4

Hasil Uji Kesetaraan Kelompok Kontrol dan Kelompok Eksperimen

\begin{tabular}{llll}
\hline \multirow{2}{*}{ Jenis Uji } & \multicolumn{2}{c}{ Uji Prasyarat } & \multicolumn{1}{c}{ Uji Lanjut } \\
\cline { 2 - 4 } Jenis Uji & \multicolumn{1}{c}{ Normalitas } & \multicolumn{1}{c}{ Homogenitas } & \multicolumn{1}{c}{ Uji Beda } \\
Sig. & Solmogorov- & Levene's test & $\begin{array}{l}\text { Independent sample } \\
\text { t-test }\end{array}$ \\
& $\begin{array}{l}\text { Eksperimen } 0,630 \\
\text { Kesimpulan }\end{array}$ & 0,151 & 0,077 \\
& $\begin{array}{l}\text { Kontrol 0,758 } \\
\text { Data normal }\end{array}$ & Kedua kelas & Tidak ada perbedaan \\
& & homogen & $\begin{array}{l}\text { antara kelas eksperimen } \\
\text { dan kelas kontrol }\end{array}$ \\
\hline
\end{tabular}


Tabel 5

Hasil Uji Efektivitas

\begin{tabular}{llll}
\hline \multirow{2}{*}{ Jenis Uji } & \multicolumn{2}{c}{ Uji Prasyarat } & \multicolumn{1}{c}{ Uji Lanjut } \\
\cline { 2 - 4 } Jenis Uji & \multicolumn{1}{c}{ Normalitas } & Homogenitas & \multicolumn{1}{c}{ Uji Beda } \\
Sig. & $\begin{array}{l}\text { Smirnov } \\
\text { Eksperimen } 0,851\end{array}$ & $\begin{array}{l}\text { Levene's test } \\
\text { Kontrol 0,521 }\end{array}$ & Independet sample t-test \\
Kesimpulan & $\begin{array}{l}\text { Data normal } \\
\text { Kedua kelas } \\
\text { homogen }\end{array}$ & $\begin{array}{l}\text { Bahan ajar yang dikembangkan } \\
\text { lebih efektif dari bahan ajar } \\
\text { yang sudah ada }\end{array}$ \\
\hline
\end{tabular}

aktivitas ilmiah dalam buku ajar mampu memfasilitasi perkembangan keterampilan berpikir siswa. Selain itu, dengan buku ajar berbasis Sains Teknologi Masyarakat, peserat didik akan belajar memecahkan masalah yang terjadi di lingkungan masyarakat sehingga keterampilan siswa dalam memecahkan permasalahan menjadi lebih baik (Yasa, 2018). Keadaaan ini memfasilitasi peningkatan penguasaan materi pembelajaran oleh peserta didik. Hasil penelitian ini sejalan dengan studi sebelumnya yang menerapkan bahan ajar IPA berbasis science literacy (Avikasari, Rukayah, \& Indriayu, 2018) dan berbasis sains, lingkungan dan teknologi (Sugiyanto, Kartika, \& Purwanto, 2012) yang secara efektif mendorong pencapaian hasil belajar peserta didik menjadi lebih baik.
Selain hipotesis yang diuji, dilakukan juga uji keberterimaan buku ajar untuk digunakan di sekolah sebagai buku ajar berbasis Sains Teknologi Masyarakat yang baik juga dilakukan melalui Focus Group Discussion (FGD) dengan enam orang validator yang terdiri dari kepala sekolah, guru, dan pengawas dengan hasil validasi yang disajikan pada Tabel 6.

Tabel 6 menunjukkan bahwa seluruh validator memberikan keberterimaan yang sangat baik pada produk bahan ajar IPA berbasis Sains Teknologi Masyarakat yang dikembangkan. Hasil wawancara juga menyatakan bahwa seluruh validator menyatakan bahwa bahan ajar yang dikembangkan praktis untuk digunakan.

Tabel 6

Hasil Keberterimaan Bahan Ajar

\begin{tabular}{lcccccc}
\hline \multicolumn{1}{c}{ Komponen Penilaian } & \multicolumn{7}{c}{ Skor Validator } \\
\hline Penyajian Bahan Ajar & V1 & V2 & V3 & V4 & V5 & V6 \\
Kedalaman dan Keluasan Materi & 36 & 37 & 40 & 38 & 40 & 40 \\
Penulisan dan Penggunaan Bahasa & 40 & 44 & 42 & 42 & 40 & 43 \\
Komponen Bahan Ajar & 23 & 22 & 25 & 23 & 25 & 23 \\
Jumlah Skor & 138 & 143 & 150 & 146 & 149 & 146 \\
Persentase (\%) & 89 & 92 & 97 & 94 & 96 & 94 \\
\hline
\end{tabular}




\section{SIMPULAN}

Pengembangan bahan ajar IPA berbasis Sains Teknologi Masyarakat yang dikembangkan melalui beberapa kali uji coba dan revisi dapat dinyatakan layak untuk digunakan pada pembelajaran IPA SD. Selain itu hasil uji efektivitas menunjukkan bahwa bahan ajar yang dikembangkan terbukti efektif dengan memberikan hasil belajar peserta didik lebih baik dibandingkan dengan yang tidak menggunakan bahan ajar yang dikembangkan. Hasil keberterimaan juga menunjukkan bahwa bahan ajar ini dapat diterima dengan sangat baik oleh para validator.

Implikasi praktis dari pengembangan bahan ajar ini diharapkan para guru di sekolah dapat menggunakan bahan ajar IPA berbasis Sains Teknologi Masyarakat ini. Dengan penggunaan oleh para guru SD, diharapkan akan memberikan kemanfaatan lebih pada bahan ajar ini.

\section{DAFTAR PUSTAKA}

Avikasari, Rukayah, \& Indriayu, M. (2018). Keefektifan penggunaan bahan ajar science literacy terhadap peningkatan prestasi belajar. Jurnal Kependidikan, 2(2), 221-234.

Belawati, T. (2003). Pengembangan bahan ajar. Jakarta: Universitas Terbuka.

Binadja, A. (2006). Pedoman pengembangan silabus bervisi dan berpendekatan SETS (Science, Environment, Technology, and Society) atau (Sains, Lingkungan, Teknologi dan Masyarakat) bahan pembelajaran penerbitan khusus media MIPA UNNES. Semarang: Laboratorium SETS. Universitas Negeri Semarang.

Cook, M. (2008). Students' comprehension of science concepts depicted in textbook illustrations. Electronic Journal of Science Education, 12(1), 1-14.
Depdiknas. (2008). Panduan pengembangan bahan ajar. Jakarta: Direktoral Jendral Manajemen Pendidikan Dasar dan Menengah.

Direktorat Pembinaan SMA. (2017). Panduan implementasi kecakapan abad 21 Kurikulum 13 di Sekolah Menegah Atas. Jakarta: Direktorat Jenderal Pendidikan Dasar dan Menengah Kemdikbud.

Gall, M. D., Borg, W. R., \& Gall, J. (2003). Educational research. An introduction ( $7^{\text {th }}$ ed.). New Jersey: Pearson.

Gusmedi, N., Hasra, A., \& Kamus, Z. (2013). Pengaruh penerapan lembar kerja siswa berbasis sains teknologi masyarakat terhadap hasil belajar fisika kelas VIII SMPN 18 Padang. Pillar of Physics Education, 2(1), 81-88.

Nurohman, S. (2006). Penerapan pendekatan sains teknologi masyarakat (STM) dalam pembelajaran IPA sebagai upaya peningkatan life skill peserta didik. Majalah Ilmiah Pembelaiaran, 2(1), 59-71.

Pedretti, E. (2003). Teaching science, technology, society and environment (STSE) education. Dalam Dana L. Zeidler(Ed.), The role of moral reasoning on socioscientific issues and discourse in science education (pp. 219-239). Dordrecht: Springer.

Prastowo, A. (2012). Panduan kreatif membuat bahan ajar inovatif. Yogyakarta: Diva Press.

Rosyidah, A. N., Sudarmin, \& Kusoro, S. (2013). Pengembangan modul IPA berbasis etnosains zat aditif dalam bahan makanan untuk kelas VIII SMP Negeri 1 Pegandon Kendal. Unnes Science Education Journal, 2(1), 133-139.

Sinatra, G. M., \& Broughton, S. H. (2011). Bridging reading comprehension 
and conceptual change in science education: The promise of refutation text. Reading Research Quarterly, 46(4), 374-393.

Sugiyanto, Kartika, I., \& Purwanto, J. (2012). Pengembangan modul IPA terpadu berbasis sains-lingkunganteknologimasyarakat dengan tema teknologi biogas. Jurnal Kependidikan: Penelitian Inovasi dan Pembelajaran, 42(1), 54-60.

Suherman, E. (2008). Model belajar dan pembelajaran berorientasi kompetensi siswa. Educare: Jurnal Pendidikan dan Budaya, 5(2), 1-31.

Rahmawati, D., Rahman, T., \& Amprasto, A. (2017, September). Efforts to handle waste through science, en- vironment, technology and society (SETS). Journal of Physics: Conference Series, 895(1), p. 012124.

Titin, Sunarno, W., \& Masykuri, M. (2012). Pembelajaran biologi menggunakan model sains teknologi masyarakat (STM) berbasis proyek untuk meningkatkan hasil belajar, dan sikap peduli lingkungan. Jurnal Inkuiri, 1(3), 245-257.

Wisudawati, A. W., \& Sulistyowati, E. (2014). Metodologi pembelajaran IPA. Jakarta: Bumi Aksara.

Yasa, A. D. (2018). Pengembangan modul tematik berbasis STM (Sains, Teknologi dan Masyarakat). Jurnal Pemikiran dan Pengembangan SD, 6(1), 21-26. 